\title{
Macroeconomic Stability in Resource-rich Countries: The Role of Fiscal Policy
}

\author{
Elva Bova ${ }^{1}$ \\ ${ }^{a}$ European Commission, Belgium \\ elvabova@gmail.com \\ Paulo Medas \\ International Monetary Fund, USA \\ pmedas@imf.org \\ Tigran Poghosyan \\ International Monetary Fund, USA \\ tpoghosyan@imf.org
}

\begin{abstract}
Resource-rich countries face large and persistent shocks, especially coming from volatile commodity prices. Given the severity of the shocks, it would be expected that these countries adopt countercyclical fiscal policies to help shield the domestic economy, either through larger spending at times of commodity busts or lower spending during commodity booms. Taking advantage of a new dataset covering 48 non-renewable commodity exporters for the period 1970-2014, we investigate whether fiscal policy does indeed play a stabilizing role. Our analysis shows that fiscal policy tends to have a procyclical bias (mainly via expenditures) and, contrary to others, we do not find evidence that this bias has declined in recent years. Further, we find that the adoption of fiscal rules does not seem to reduce procyclicality in a significant way, but the quality of political institutions does matter. Finally, we find that non-commodity revenues tend to respond only to persistent changes in commodity prices.
\end{abstract}

JEL classification: $\mathrm{O} 13, \mathrm{H} 30, \mathrm{C} 33$

Keywords: commodity prices, resource-rich countries, procyclical fiscal policy, fiscal rules.

\section{INTRODUCTION}

The 2012 fall in energy prices once again shifted the attention of policymakers to commodity price shocks and their impact on macroeconomic stability in resource-rich countries. Movements in commodity prices affect these economies directly through the external trade balance (commodity 
exports) and the public sector budget as governments receive a large share of commodity sector revenues. There are also indirect channels, such as changes in borrowing conditions, asset prices, and investment. Given the high dependence on budgetary commodity revenues and exports, the large price fluctuations imply these countries are exposed to large external risks.

A key policy objective for resource-rich countries is to shield the economy from the high volatility of commodity prices. The traditional advice is for countries to develop stabilizing (countercyclical) fiscal policies towards helping smooth the business cycle (IMF 2015b). This is a more complex and critical challenge for non-renewable resource-rich economies. A central issue is that the economic cycle tends to be closely linked to unpredictable fluctuations in commodity prices. These can be very large and persistent and lead to disruptive large swings in the domestic economic activity, exacerbated (as has been seen in the past) by large increases in public expenditures during commodity booms and large fiscal contractions once prices fall. Furthermore, if fiscal policy is heavily procyclical during upswings - that is, governments spend a large share (or all) of temporary commodity revenue windfalls - this will have an impact on fiscal sustainability as these are exhaustible resources.

This paper aims to assess whether fiscal policy has helped manage high volatility of commodity prices. We contribute to the literature by: (i) using a new dataset starting from 1970, (ii) assessing the importance of fiscal channel in the transmission of commodity price shocks, and (iii) applying a comprehensive set of indicators to study fiscal cyclicality in resource-rich countries, which also encompass the cyclicality of non-commodity revenue.

Our results show that fiscal policy in resource-rich countries has been procyclical during the last decades. We also find no evidence of reduced procyclicality during the resource windfall in the 2000s, contrary to other studies (see below). Regression analysis also suggests that the adoption of fiscal rules does not have, on its own, a significant impact on reducing procyclicality, unless supported by strong political institutions. Through the examination of the impact of commodity prices on non-commodity revenues, we find that the revenue mobilization efforts decline with rising commodity prices. Non-commodity revenues adjust only in response to persistent changes in commodity revenues as this adjustment tends to be sluggish.

The remainder of the paper is structured as follows. Section II reviews the related literature. Section III describes the dataset. Section IV assesses the direct impact of commodity price fluctuations on the economy. Section V presents evidence on fiscal cyclicality and on the role of fiscal rules and institutions. Section VI analyzes the response of non-commodity revenues to commodity revenue shocks. The final section concludes.

\section{LITERATURE REVIEW}

A growing empirical literature analyzes fiscal policy responses to output fluctuations in advanced and emerging economies. Several approaches have been taken to assess fiscal cyclicality. For instance, the Fiscal Monitor (IMF 2015b) looks at the overall fiscal balance to GDP ratio and interprets the response to output fluctuations as a measure of fiscal stabilization (the sum of automatic stabilizers and discretionary fiscal policy). Similar measures have been used by Gavin and Perotti (1997) and Alesina et al. (2008). Other studies have used the cyclically adjusted fiscal balance to GDP ratios and interpreted the response to output fluctuations as discretionary fiscal policy reaction to economic shocks (e.g., Gali and Perotti, 2003). Some have focused on cyclically adjusted government spending as a measure of discretionary government spending, taking into account that automatic stabilizers mostly work on the revenue side (Kaminsky et al., 2004; Frankel et al., 2013). The most popular measure of output fluctuations is the output gap (e.g., Kaminsky et al., 2004). However, given the difficulty in measuring potential output, some studies have also used real GDP growth as a measure of output fluctuations (IMF 2015b) or used 
cointegration methodology to assess both long-run and short-run association between government spending and output (Akitoby et al., 2006).

These studies find that fiscal policies tend to be more successful in smoothing the impact of economic shocks in advanced economies than in developing or emerging economies (e.g. IMF, 2015b, Akitoby et al., 2006), even though some emerging economies have recently improved (Frankel et al., 2013).

Only a few studies analyze fiscal policy cyclicality in resource-rich countries. Given the high dependence on commodity revenues, the standard methods mentioned above cannot be applied to these countries. The main difficulty is that both fiscal policy indicators and output fluctuations are heavily affected by movements in commodity prices. For instance, a positive shock to commodity prices would result in higher output and would simultaneously improve the fiscal balance. In a regression framework, the automatic response to commodity price changes could result in a spurious association between the fiscal variable and output fluctuations.

To overcome these issues, two approaches have been proposed in the literature. One is based on measuring the reaction of government spending to changes in commodity prices (Arezki et al., 2011; Cespedes and Velasco, 2014). Acyclical fiscal policy implies that government spending dynamics should be delinked from movements in commodity prices, while procyclical fiscal policy implies a positive association between the two. Given that automatic stabilizers are mostly working on the revenue side, positive association between government spending and commodity prices can be interpreted as a procyclical discretionary policy.

Another approach is based on assessing the fiscal stance over the economic cycle after correcting for the impact of commodity prices (Villafuerte et al., 2010). This approach looks at the relationship between the non-resource fiscal balance and the output gap of the non-resource economy. ${ }^{2}$ A positive association between cyclically adjusted non-resource balance and nonresource output gap indicates countercyclical reaction of discretionary fiscal policy (excluding its commodity component) to disturbances in the non-commodity part of the economy.

Evidence from these studies suggests that fiscal policies do tend to be procyclical, but appear to have become less so in recent years. Using a sample of 32 countries, Cespedes and Velasco (2014) argue that while fiscal policy was procyclical in many countries in the $1970 \mathrm{~s}-80 \mathrm{~s}$, this was not the case in the 2000 s resource windfall. They attribute this to improvements in institutional quality. However, their sample includes a variety of countries, and goes beyond large non-renewable commodity exporters covered in our sample. In addition, some of the results are influenced by using the overall fiscal balance (and other indicators) as a share of nominal GDP, which can distort the analysis. Abdih et al. (2010) argue that policies in 28 oil-exporting countries were procyclical on average, but many countries adopted countercyclical policies in response to the international crisis in 2009. Villafuerte et al. (2010), using a similar approach for a sample of Latin American countries, also find evidence of procyclicality. Erbill (2011) finds that between 1990 and 2009 political stability and higher quality of institutions combined with less binding financial constraints are associated with lower procyclicality of fiscal policy in oil exporters.

Our analysis contributes to the literature in several directions. First, we study whether policies have been procyclical using alternative approaches. Second, we take advantage of a longer time period, including the latest period of high commodity prices (1970-2014), and a larger sample of non-renewable resource-rich countries (both oil/gas and metals). Third, our focus is on countries which are more dependent on commodity resources and, as such, likely to be more affected by volatility in commodity prices. Finally, our dataset includes data on non-resource fiscal balances and non-resource GDP allowing a more robust assessment of the fiscal stance than some of the previous work.

\footnotetext{
The non-resource fiscal balance is measured as the difference between overall balance and commodity revenues, while non-resource GDP excludes the commodity sector/production. The output gap is measured as the difference between the actual and potential output.
} 


\section{DATA SOURCES}

To assess fiscal policy responses to commodity price fluctuations through different channels, this study uses a novel dataset with annual data covering the period 1970 to 2013 . The dataset combines information from multiple primary sources. For commodity prices, it uses monthly data from the IMF World Economic Outlook database for the 1957-2015 period. For other commodity related data (weights in total exports, value added...) the dataset considers the IMF Balance of Payments Statistics and Direction of Trade Statistics databases. For country specific macroeconomic variables, the dataset contains variables from the International Financial Statistics and World Economic Outlook databases of the IMF. These databases provide also data on fiscal variables which have been complemented by series from the Governance Finance Statistics database, including on the components of spending and revenue. For governance indicators, it relies on the IMF fiscal rules dataset; the World Bank's World Development Indicators and World Governance Indicators; the Macro Data Guide Political Constraint Index Dataset (POLCON); POLITY IV and International Country Risk Guide.

The sample comprises 48 countries that are exporters of oil, gas, and metals (such as copper, gold, iron, and silver), where these commodities represent a large share of exports (20 percent or more of total exports) or fiscal revenues (15 percent or more) on average for a five-year period (either 2007-11 or 2009-13, depending on data availability). The countries are: Algeria, Angola, Australia, Azerbaijan, Bahrain, Bolivia, Botswana, Brunei Darussalam, Cameroon, Canada, Chad, Chile, Colombia, Democratic Republic of Congo, Republic of Congo, Côte d'Ivoire, Ecuador, Gabon, Ghana, Guinea, Guyana, Indonesia, Iran, Iraq, Kazakhstan, Kuwait, Libya, Mali, Mauritania, Mexico, Mongolia, Nigeria, Norway, Oman, Papua New Guinea, Peru, Qatar, Russia, Saudi Arabia, South Africa, Sudan, Suriname, Syria, Trinidad and Tobago, United Arab Emirates, Venezuela, Yemen, and Zambia. The dataset is an unbalanced panel as some observations are missing for the time series around the 1970s and 1980s, in particular for some developing countries.

\section{THE SIZE AND IMPACT OF COMMODITY PRICE FLUCTUATIONS}

Resource-rich countries face large and unpredictable commodity price fluctuations. We define phases of expansions and contractions using the Harding and Pagan (2002) algorithm ${ }^{3}$. Following Cashin et al. (2002), we date commodity cycles for the period 1957-2015 using a minimum duration of each phase of 12 months, and a 24-month minimum duration for a complete cycle. Commodity prices are expressed in US dollars and deflated by the US GDP deflator. We find that the average duration of commodity price upswings (downswings) is 2-4 years, but the standard deviation is large and some periods of price expansion (contraction) can last up to 10 years (Tables 1-2). The average amplitude of changes in real commodity prices during periods of booms (percentage change from trough to peak) and busts (percentage change from peak to trough) is large, ranging from 40-50 percent (e.g. for iron ore) and 80 percent (e.g. for natural gas) for booms and 35-80 percent for busts (Table 3). Some of the booms (busts) are characterized by much larger amplitude of price changes, sometimes exceeding 200 percent. The duration of booms and busts in the metals, minerals, and oil sectors tends to be relatively longer because of the longer lags between investing in new capacity and the eventual increase in supply (World Bank, 2009). The standard deviation is also large suggesting high variability of commodity prices, which makes it difficult for policy makers to predict when current price cycles would end.

\footnotetext{
The algorithm identifies potential turning points as the local minima and maxima in the series. Candidate points must satisfy two conditions: minimum length of phases and minimum length of complete cycles. The minimum lengths for both are parameters to be chosen by the researcher.
} 
Table 1.

Descriptive statistics: commodity price growth rates

\begin{tabular}{|c|c|c|c|c|c|c|c|}
\hline & Sample & Obs. & Mean & Median & St. Dev & Skeweness & Kurtosis \\
\hline Aluminum & $\begin{array}{c}\text { Feb } 1957- \\
\text { Jan } 2015\end{array}$ & 696 & -0.133 & -0.188 & 4.66 & -0.504 & 8.380 \\
\hline Copper & $\begin{array}{c}\text { Feb } 1957- \\
\text { Jan } 2015\end{array}$ & 696 & -0.009 & 0.084 & 6.63 & -0.477 & 6.351 \\
\hline Gold & $\begin{array}{c}\text { Feb } 1957- \\
\text { Jan } 2015\end{array}$ & 612 & 0.254 & -0.199 & 4.69 & 1.091 & 11.563 \\
\hline Iron Ore & $\begin{array}{c}\text { Feb } 1957- \\
\text { Jan } 2015\end{array}$ & 480 & 0.145 & -0.295 & 5.56 & 3.812 & 36.452 \\
\hline Gas (EU) & $\begin{array}{c}\text { Feb } 1985- \\
\text { Jan } 2015\end{array}$ & 360 & 0.033 & -0.206 & 6.43 & -0.635 & 18.460 \\
\hline Gas (US) & $\begin{array}{c}\text { Feb } 1991- \\
\text { Jan } 2015\end{array}$ & 288 & 0.063 & -0.310 & 13.34 & -0.042 & 3.950 \\
\hline Tin & $\begin{array}{c}\text { Feb } 1957- \\
\text { Jan } 2015\end{array}$ & 696 & 0.008 & -0.107 & 4.98 & -0.474 & 6.719 \\
\hline Oil (Brent) & $\begin{array}{c}\text { Feb } 1957- \\
\text { Jan } 2015\end{array}$ & 696 & 0.146 & -0.243 & 8.38 & 4.354 & 65.932 \\
\hline Oil (texas) & $\begin{array}{c}\text { Feb } 1957- \\
\text { Jan } 2015\end{array}$ & 696 & 0.099 & -0.279 & 7.11 & 2.088 & 34.853 \\
\hline
\end{tabular}

Note: Reported are descriptive statistics for real m-o-m growth rates

Source: IMF World Economic Outlook.

Table 2.

Duration in months of commodity price expansions and contractions

\begin{tabular}{llcccccc}
\hline \hline \multirow{2}{*}{ Aluminum } & Mean & Median & St.Dev & Freq. & Min & Max \\
& Expansions & 29.3 & 18.0 & 24.4 & 11 & 11 & 86 \\
& Contractions & 34.1 & 34.0 & 14.6 & 11 & 12 & 65 \\
\multirow{2}{*}{ Copper } & Expansions & 38.5 & 24.5 & 33.0 & 8 & 17 & 112 \\
& Contractions & 43.2 & 44.0 & 26.9 & 9 & 12 & 81 \\
\multirow{3}{*}{ Gold } & Expansions & 36.4 & 26.0 & 38.7 & 8 & 3 & 125 \\
& Contractions & 40.3 & 33.5 & 22.1 & 8 & 17 & 79 \\
\multirow{3}{*}{ Iron Ore } & Expansions & 29.2 & 13.0 & 34.6 & 6 & 12 & 99 \\
& Contractions & 43.7 & 47.0 & 20.9 & 7 & 11 & 72 \\
\multirow{2}{*}{ Gas-EU } & Expansions & 30.8 & 24.5 & 23.9 & 6 & 7 & 76 \\
& Contractions & 29.3 & 27.0 & 13.6 & 6 & 15 & 53 \\
\multirow{2}{*}{ Gas-US } & Expansions & 23.8 & 19.0 & 15.9 & 6 & 13 & 55 \\
& Contractions & 20.9 & 15.0 & 14.5 & 7 & 6 & 47 \\
\hline
\end{tabular}




\begin{tabular}{llcccccc}
\hline & & Mean & Median & St.Dev & Freq. & Min & Max \\
\hline \multirow{2}{*}{ Tin } & Expansions & 25.1 & 23.0 & 8.8 & 11 & 12 & 38 \\
& Contractions & 35.1 & 19.0 & 46.5 & 12 & 14 & 179 \\
\multirow{3}{*}{ Oil-Brent } & Expansions & 28.3 & 21.0 & 20.5 & 11 & 12 & 79 \\
& Contractions & 32.2 & 23.5 & 30.3 & 12 & 8 & 107 \\
\multirow{3}{*}{ Oil-Texas } & Expansions & 28.3 & 22.5 & 21.3 & 10 & 12 & 78 \\
& Contractions & 37.6 & 23.0 & 35.1 & 11 & 8 & 115 \\
\hline \hline
\end{tabular}

Source: IMF World Economic Outlook and authors' calculations.

Table 3.

Amplitude of commodity price expansions and contractions

\begin{tabular}{|c|c|c|c|c|c|c|c|}
\hline & & Mean & Median & St.Dev & Freq. & Min & Max \\
\hline \multirow{2}{*}{ Aluminum } & Expansions & 40.9 & 52.4 & 35.0 & 11.0 & 1.6 & 107.1 \\
\hline & Contractions & -51.6 & -49.6 & 42.2 & 11.0 & -140.0 & -6.2 \\
\hline \multirow{2}{*}{ Copper } & Expansions & 78.6 & 70.2 & 45.6 & 8.0 & 25.2 & 172.0 \\
\hline & Contractions & -72.4 & -85.4 & 34.5 & 9.0 & -113.1 & -17.1 \\
\hline \multirow{2}{*}{ Gold } & Expansions & 63.3 & 28.9 & 64.3 & 8.0 & 7.3 & 166.1 \\
\hline & Contractions & -47.5 & -48.5 & 24.4 & 8.0 & -91.1 & -9.9 \\
\hline \multirow{2}{*}{ Iron Ore } & Expansions & 50.4 & 14.4 & 96.0 & 6.0 & 0.9 & 245.6 \\
\hline & Contractions & -35.9 & -27.3 & 35.5 & 7.0 & -107.6 & -5.9 \\
\hline \multirow{2}{*}{ Gas-EU } & Expansions & 63.6 & 54.2 & 58.7 & 6.0 & 3.0 & 168.8 \\
\hline & Contractions & -63.4 & -58.7 & 30.5 & 6.0 & -113.0 & -21.5 \\
\hline \multirow{2}{*}{ Gas-US } & Expansions & 80.1 & 84.3 & 25.1 & 6.0 & 33.7 & 110.5 \\
\hline & Contractions & -78.9 & -69.5 & 49.3 & 7.0 & -154.9 & -14.4 \\
\hline \multirow{2}{*}{ Tin } & Expansions & 50.6 & 49.3 & 34.2 & 11.0 & 9.0 & 117.1 \\
\hline & Contractions & -47.8 & -44.6 & 48.2 & 12.0 & -192.2 & -12.3 \\
\hline \multirow{2}{*}{ Oil-Brent } & Expansions & 63.0 & 57.3 & 51.5 & 11.0 & 4.2 & 175.4 \\
\hline & Contractions & -57.8 & -51.2 & 43.6 & 12.0 & -162.7 & -2.9 \\
\hline \multirow{2}{*}{ Oil-Texas } & Expansions & 65.5 & 63.0 & 50.6 & 10.0 & 0.4 & 166.7 \\
\hline & Contractions & -51.8 & -45.7 & 40.1 & 11.0 & -138.6 & -9.3 \\
\hline
\end{tabular}

Source: IMF World Economic Outlook and authors' calculations. 
The volatility in commodity prices can have a large impact on the external current and fiscal accounts. The average direct impact can be estimated based on the average amplitude of commodity price changes and applying it to exports and fiscal revenues of resource-rich countries.

As illustrated in Figure 1, the average impact can be large, ranging from 8-13 percent of GDP for exports and 2-10 percent of GDP for fiscal revenue during upswings and a negative impact between 3-16 percent of GDP for revenue and 9-13 for exports during downswings. The relatively larger impact on fiscal revenues in oil exporters suggests that transmission of commodity price shocks to the economy mostly works through the fiscal channel. This is in line with results of Husain et al. (2008). There is also evidence of asymmetry across phases of the commodity price cycle, with the impact being stronger in downswings compared to upswings.

Figure 1.

Impact of commodity price swings on fiscal revenues and exports

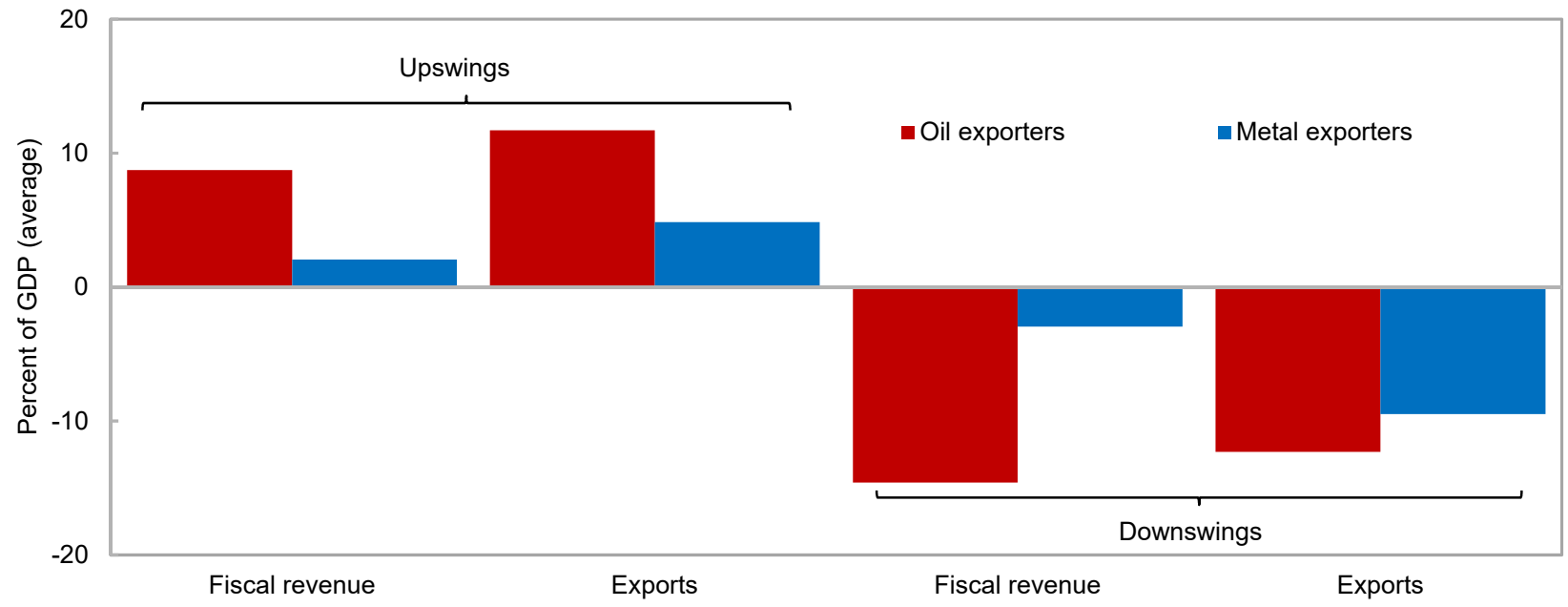

Source: IMF World Economic Outlook and authors' estimates.

Past and recent experiences also show that shocks can be very large for the budget and the economy. Typically, economic activity and external and fiscal balances deteriorate (improve) during commodity price downswings (upswings). ${ }^{4}$ These price fluctuations can have a significant impact on growth. The bar chart in figure 2 reports the median of the growth rate of real revenue and expenditure for resource rich countries that experienced revenue increases over the 1973-80 boom. It indicates that during the 1970s-80s boom and bust, many countries experienced revenue increases of close to 10 percent a year in real terms during the boom and subsequent falls in the bust. This led to large increases in public expenditures and economic activity. But, after the bust, many commodity exporters experienced a long period of negative or stagnant growth. Similarly, many commodity exporters - after experiencing large revenue windfalls in the $2000 \mathrm{~s}$ - had subsequently to manage a large fall in commodity prices.

4 See April 2012 IMF World Economic Outlook. 
Figure 2.

The 1970s-80s boom-bust and its impact on growth
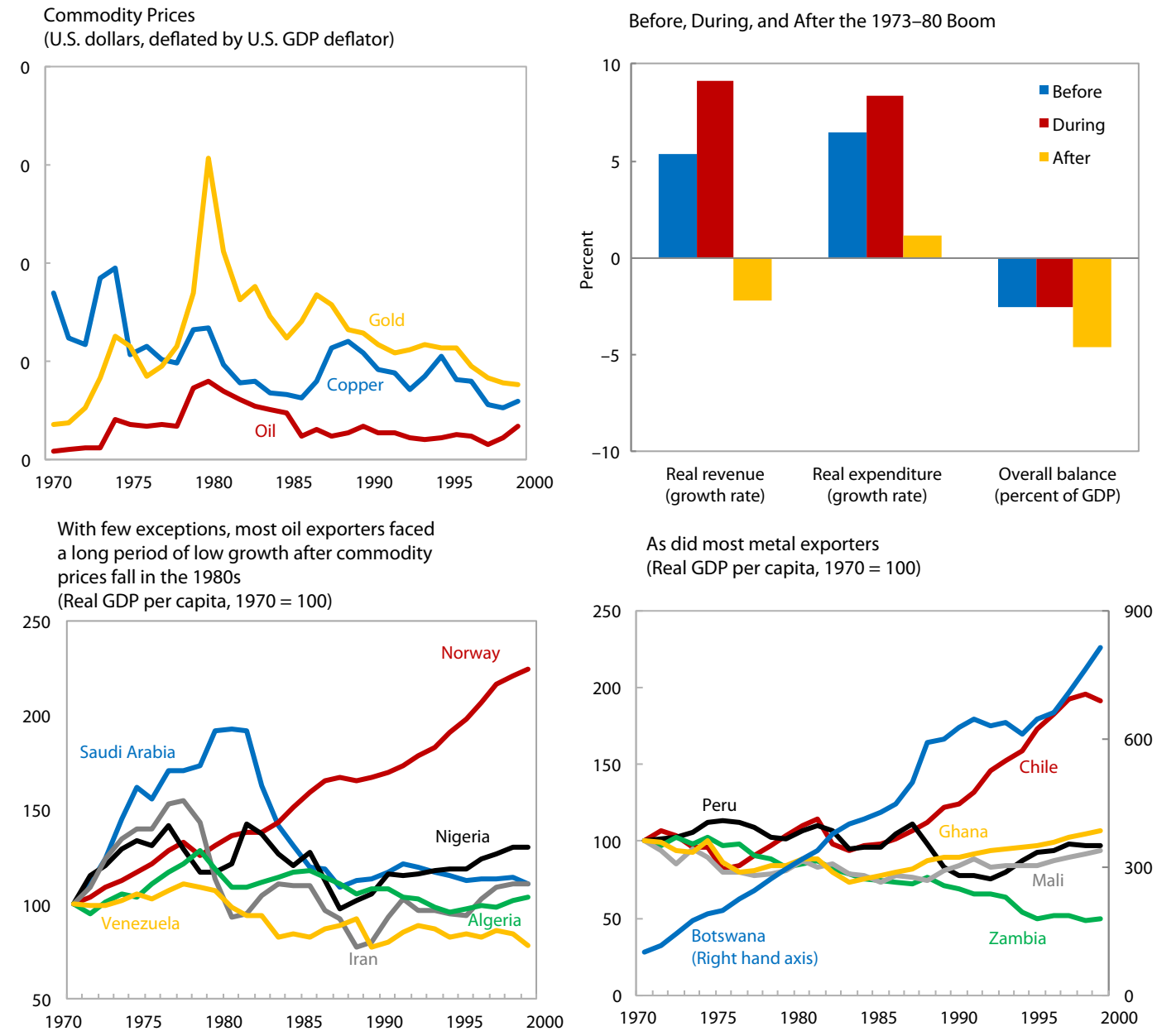

Note: For panel 2, before $=1971-72$, during $=1973-80$, after 1982-83.

Source: IMF World Economic Outlook and authors' calculations.

\section{FISCAL CYCLICALITY}

As shown in the literature, by exacerbating output volatility, procyclical fiscal policy could dampen economic growth. Fatas and Mihov (2003) show that aggressive use of discretionary fiscal policy adds to economic volatility and lowers economic growth. The Fiscal Monitor (IMF 2015 b) finds that an increase in fiscal stabilization could boost long-run annual growth rates of developed economies significantly. Van der Ploeg and Poelhekke (2008) also show that volatility hurts growth among commodity exporters, with the former partially explained by volatile government expenditures.

Resource-rich countries should benefit from countercyclical policies to a greater extent than other countries. As the large volatility in prices is transmitted to the economy, this could lead to large swings in the economy. Fiscal policy can help stabilize the economy, especially as the government usually receives a large share of commodity receipts. However, evidence seems to suggest that fiscal policy, in many cases, has exacerbated the impact of volatile prices (Gelb and associates, 1998). Some argue policies have become less procyclical (or even countercyclical) in recent years (Frankel et al., 2013; Cespedes and Velasco, 2014). However, many countries raised expenditures massively during the revenue windfall of the 2000s and were forced to large procyclical expenditure cuts during the 2012 slump (IMF 2015a). 
We revisit the evidence on fiscal cyclicality and whether it has changed over time, especially during the resource boom of the 2000s, taking advantage of our new data. In order to formally answer these two questions, we apply two different approaches. The first measures the responsiveness of public expenditure growth rates to year-to-year changes in commodity prices. The second assesses how fiscal policy is reacting to the business cycle in the non-resource sector. This section outlines these methods and their results.

\subsection{Empirical strategy}

The first approach entails estimating the relationship between commodity prices and fiscal policy. Following Kaminsky et al. (2004), we use government expenditures as our measure of fiscal policy. This is particularly relevant for resource-rich countries, as historical experience shows fiscal policy tends to react to movements in commodity prices mainly via expenditures. A positive association indicates that fiscal policy is procyclical, as government spending would increase in periods of economic expansion fueled by growing commodity prices. The advantage of this approach is that commodity prices are exogenous to domestic economic cycles and spending policies, which alleviates endogeneity issues.

The empirical specification takes the following form:

$$
\Delta \log \left(R G_{i t}\right)=\alpha_{i}+\beta \Delta \log \left(P_{i t}\right)+\varepsilon_{i t},
$$

in which $R G$ is the real government spending. $P$ is the country-specific commodity price index. We use a fixed effects panel to estimate the coefficient $\beta$, our indicator of cyclicality. It measures the elasticity of government expenditures to the commodity price index. A positive value of $\beta$ implies procyclical behavior.

$\mathrm{P}$ is measured as:

$$
P_{i t}=\sum_{j \in J} P_{i j t} * w_{i j}
$$

in which $i$ is the country, $j$ is the commodity type (oil, gas, gold, tin, zinc, lead, aluminum, nickel, copper, and silver), $P$ is the real commodity price (deflated by the U.S. consumer price index, $\mathrm{CPI}$ ), and $w$ is the commodity weight (commodity export share in GDP).

By using changes of government spending and commodity price variables we are abstracting from the possible long-run correlation of their levels. In addition, we found no evidence of a longterm relationship between the two. ${ }^{5}$ Changes of these variables proxy cyclical movements and positive association between changes is an indication of procyclicality. We also assess whether there are differences in procyclicality across expansionary and contractionary phases of the cycle, by interacting commodity price changes with a dummy variable indicating the cyclical phase. We also study whether the relationship differs between total and capital expenditure, as capital expenditure tends to be the first to adjust to shocks.

The second approach examines the relationship between output gap and cyclically adjusted fiscal balances. If this relationship is negative, then fiscal policy is procyclical. As mentioned above, for resource-rich countries, an appropriate indicator of the fiscal stance is the non-resource fiscal balance as a share of the non-resource GDP. Using the overall balance would lead to a bias when measuring fiscal cyclicality (Villafuerte et al., 2010). ${ }^{6}$ The empirical specification takes the following form:

\footnotetext{
5 The long-term relationship could be positive as countries could afford higher (lower) spending when prices are higher (lower). However, panel cointegration tests (Westerlund, 2007) suggest the two series are not cointegrated, which further supports our empirical approach of focusing on changes in expenditures and prices.

6 Overall fiscal balances and GDP are heavily influenced by movements in commodity prices and as such should notcannot be used to assess how policies are changed in response to prices. For example, an improvement in fiscal balances when commodity prices rise does not imply there was a tightening of the fiscal stance (the opposite may be true). Similarly, governments may react to a rise in prices by boosting expenditures and lead to a strong fiscal impulse to the domestic economy, even when the overall fiscal balance improves - thanks to a large increase in commodity revenue (originated from rising export receipts)..
} 


$$
\frac{C A_{-} B A L_{-} N C_{i t}}{G D P_{-} N C_{i t}}=\alpha_{i}+\beta G A P_{-} N C_{i t}+\varepsilon_{i t},
$$

in which $C A \_B A L \_N C$ is the cyclically adjusted non-resource balance (assuming elasticities of 1 for revenues and 0 for expenditures), GDP_NC is the non-resource GDP, and GAP_NC is the non-resource GDP gap. Coefficient b captures the degree of fiscal cyclicality (a negative coefficient implies procyclicality). Models parameters are estimated using the fixed effects regression. As a test of robustness, non-resource GDP growth is used instead of the non-resource output gap, given the high uncertainty when measuring economic cycles.

\subsection{Results}

The results of a fixed effects panel suggest that commodity prices have a positive impact on government spending (Table 4), implying a procyclical fiscal policy. A 10 percent increase (fall) in commodity prices leads to a 1.2 percent increase (fall) in real expenditure growth. This means that, for example, if oil prices fall by 50 percent, as in the second half of 2014, expenditures would contract by 6.5 percent on average at a time when economic growth is rapidly decelerating. As suspected, capital spending is even more procyclical compared to total spending (the coefficient is 0.15 and increases to 0.17 when controlling for dependence on resource revenue), suggesting that indeed such variable bears the brunt of adjustments to commodity price shocks. The results are robust when we control for the degree of dependence on resource revenue (measured as the value added to GDP of the commodity). When distinguishing between different stages of the cycle, the results suggest that procyclicality is stronger during commodity price expansions, indicating that a large part of the windfall is spent at times of booms.

Table 4.

Estimation results: government spending and commodity prices

\begin{tabular}{|c|c|c|c|c|c|c|c|c|}
\hline & I & II & III & IV & $\mathrm{V}$ & VI & VII & VIII \\
\hline & \multicolumn{4}{|c|}{ total expenditure $(R G)$ growth rate } & \multicolumn{4}{|c|}{ capital expenditure growth rate } \\
\hline D 1 comm. prices $(P)$ & $\begin{array}{l}0.119^{* *} \\
{[0.052]}\end{array}$ & & $\begin{array}{l}0.121^{* *} \\
{[0.057]}\end{array}$ & & $\begin{array}{c}0.147^{*} \\
{[0.081]}\end{array}$ & & $\begin{array}{l}0.169^{* *} \\
{[0.086]}\end{array}$ & \\
\hline \multicolumn{2}{|c|}{$\begin{array}{l}\mathrm{D} \log \text { comm. } \mathrm{p}(P)^{*} \text { Dummy } \\
(=1 \text { expansions })\end{array}$} & $\begin{array}{l}0.148^{* *} \\
{[0.059]}\end{array}$ & & $\begin{array}{l}0.157^{* *} \\
{[0.065]}\end{array}$ & & $\begin{array}{l}0.205^{* *} \\
{[0.095]}\end{array}$ & & $\begin{array}{l}0.223^{* *} \\
{[0.101]}\end{array}$ \\
\hline \multicolumn{2}{|c|}{$\begin{array}{l}\text { D } \log \text { comm. } \mathrm{p}(P)^{*} \text { Dummy } \\
(=1 \text { contractions })\end{array}$} & $\begin{array}{c}0.073 \\
{[0.068]}\end{array}$ & & $\begin{array}{c}0.070 \\
{[0.072]}\end{array}$ & & $\begin{array}{c}0.074 \\
{[0.103]}\end{array}$ & & $\begin{array}{c}0.102 \\
{[0.108]}\end{array}$ \\
\hline \multicolumn{3}{|c|}{ Comm. value added in GDP } & $\begin{array}{l}0.004^{* * *} \\
{[0.001]}\end{array}$ & $\begin{array}{l}0.004^{* * *} \\
{[0.001]}\end{array}$ & & & $\begin{array}{l}0.006^{* * *} \\
{[0.001]}\end{array}$ & $\begin{array}{l}0.006^{* * *} \\
{[0.001]}\end{array}$ \\
\hline Constant & $\begin{array}{l}0.124^{* *} \\
{[0.058]}\end{array}$ & $\begin{array}{c}0.038 \\
{[0.045]}\end{array}$ & $\begin{array}{l}-1.193 \\
{[1.281]}\end{array}$ & $\begin{array}{l}-1.198 \\
{[1.245]}\end{array}$ & $\begin{array}{c}0.055 \\
{[0.058]}\end{array}$ & $\begin{array}{c}0.017 \\
{[0.054]}\end{array}$ & $\begin{array}{c}0.029 \\
{[1.145]}\end{array}$ & $\begin{array}{c}0.034 \\
{[1.153]}\end{array}$ \\
\hline Observations & 902 & 902 & 824 & 824 & 1346 & 1346 & 1239 & 1239 \\
\hline N. of countries & 41 & 41 & 41 & 41 & 38 & 38 & 38 & 38 \\
\hline $\mathrm{R}^{\wedge} 2$ & 0.079 & 0.080 & 0.107 & 0.109 & 0.079 & 0.080 & 0.102 & 0.103 \\
\hline
\end{tabular}

Note: Dependent variables are growth rates of real total expenditure (columns I-IV) and capital expenditure (columns V-VIII). Estimations are performed using the fixed effects estimator with AR(1) residuals and time effects. Robust standard errors are in brackets. ${ }^{*},{ }^{* *}$, and ${ }^{* * *}$ denote significance at 10, 5, and 1 percent levels, respectively.

Source: IMF World Economic Outlook and authors' calculations. 
Has this procyclicality changed over time? To answer, we run the same panel regression (equation 1) repeatedly for a 10 -year rolling window and obtain a time varying coefficient reported in Figure 3. We do not find robust evidence that average procyclicality has declined since 1970. The estimated coefficients for 1980-2015 show that average procyclicality in recent years is similar to levels seen in past decades. Our result is consistent with the evidence that many resource-rich countries accelerated significantly public expenditures during the 2000s, at a time when commodity prices were exceptionally high (or rising fast). In some countries public expenditures (in real terms) more than tripled during that period (IMF 2015a).

Figure 3.

The degree of procyclicality appears to have been stable over time

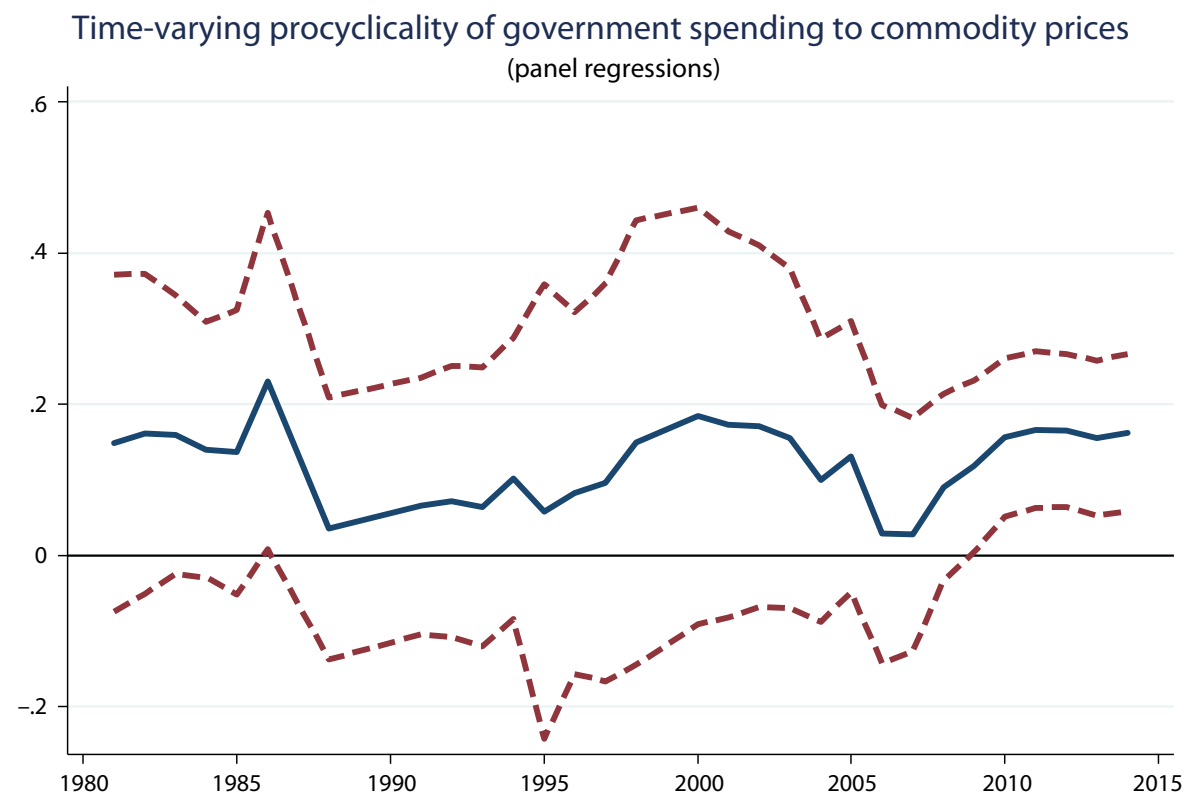

Note: Estimations are performed using 10 year rolling windows. Dashed lines represent 10 percent confidence intervals.

Source: Authors' calculations.

The results of the fixed effects panel using the second approach confirms the procyclical bias of fiscal policy. The results in Table 5, show that governments tend to loosen the fiscal stance when the domestic non-resource economy strengthens, and tighten the fiscal stance when the economy weakens. A 1 percentage point improvement in the non-resource output gap leads to a 1 percentage point deterioration of the cyclically adjusted non-resource balance as a share of potential non-commodity GDP. Replacing the output gap with real GDP growth rates (for the non-resource economy) does not alter the negative association. Moreover, the results suggest commodity exporters tend to be more procyclical than other emerging economies. Notably, IMF (2015b) found that emerging markets and developing economies also tend to act procyclically in expansions, but with a coefficient half of the size of the figure found here for commodity exporters (around 0.5). 
Table 5.

Estimation results: non-commodity output gap and cyclically-adjusted non-commodity balance

\begin{tabular}{lcc}
\hline \hline & I $C A_{-} B A L_{-} N C$ & II $C A_{-} B A L_{-} N C$ \\
\hline Non-commodity output gap $\left(G A P_{-} N C\right)$ & $-0.945^{* * * *}$ & \\
& {$[0.225]$} & $-0.215^{* * *}$ \\
Non-commodity GDP $\left(G D P \_N C\right)$ growth & {$[0.011]$} \\
& & $-0.254^{* * *}$ \\
Constant & $-0.266^{* * *}$ & {$[0.039]$} \\
Observations & {$[0.039]$} & 765 \\
Number of countries & 770 & 41 \\
$\mathrm{R}^{\wedge}$ 2 & 41 & 0.279 \\
\hline \hline
\end{tabular}

Note: Dependent variable is cyclically-adjusted non-commodity balance. Estimations are performed using the fixed effects estimator with time effects. Robust standard errors are in brackets. ${ }^{*},{ }^{* *}$, and ${ }^{* * *}$ denote significance at 10,5 , and 1 percent levels, respectively.

Source: IMF World Economic Outlook and authors' calculations.

Why fiscal policies tend to be procyclical if this leads to volatility and potentially much weaker growth? Given that commodity price shocks can be very persistent, public expenditures may be increased significantly if revenues are expected to remain high for long. Once prices disappoint, there is a need for expenditure cuts. While the decision to respond in a procyclical fashion to movements in prices may be consistent with affordability arguments (if richer, it could be optimal to raise spending), it is not so when considering stabilization objectives. As the commodity windfall is likely to boost the domestic economy, accelerating public spending may be destabilizing. ${ }^{7}$ Furthermore, countries may expand spending beyond what is feasible. For example, Manzano and Rigobon (2001) argue that the problems faced by resource-rich countries mainly reflect debt overhang as countries borrow during booms and need to adjust during busts. This, at least in part, reflects the weak political institution argument which identifies these economies as more prone to rent-seeking in the face of large commodity windfalls (Tornell and Lane, 1999).

\subsection{Can institutions help reduce procyclicality?}

In an attempt to restrict fiscal policy, many countries have adopted fiscal rules and resource funds (or sovereign wealth funds), more generally defined as special fiscal institutions. These aim at constraining the fiscal management of commodity revenues either for sustainability or stability reasons. ${ }^{8}$ In this section we look at the impact of these rules and resource funds on procyclicality.

For our analysis, we consider only rules that have been strictly designed to regulate the accumulation or use of resource revenues, including rules that are established for the functioning of a fund (either saving or stabilization fund). In some cases, funds have been established without a legally binding rule for the accumulation and withdrawal of assets. Hence, the estimation below features both a dummy for fiscal rules and a dummy for when a fund is in place (with or without a rule). To complement the analysis, we also examine the impact of broader political

\footnotetext{
7 The large scaling up of public spending could also have a negative impact on its quality and effectiveness. See IMF (2015a) for more discussion on this.

8 These fiscal rules are different from the more common rules aimed at restricting fiscal policy at large and adopted also by countries other than resource rich (for a description of the latter see Schaechter et al., 2012, and the IMF database http://www.imf.org/external/datamapper/FiscalRules/ map/map.htm). Other types of special fiscal institutions include stabilization funds, saving funds, and investment funds when the latter are related to the investment of resource receipts (see table A.1 in the appendix with the rules and institutions considered in this paper).
} 
institutions. We use some of the World Governance Indicators and the International Risk Group databases; notably bureaucratic quality, corruption, political risk and strength of the institutional and legal setting. The Polity variable comes from the Polity IV dataset and captures the quality of democratic institutions and rule of law. For these variables, a higher value means a better institutional quality.

To assess the impact of the different institutions, the empirical strategy involves interacting the commodity price index with measures of institutional quality and fiscal rules/resource funds. The empirical specification takes the following form:

$$
\Delta \log \left(R G_{i t}\right)=\alpha_{i}+\beta \Delta \log \left(P_{i t}\right)+\gamma \Delta \log \left(P_{i t}\right) * I_{i t}+\varepsilon_{i t}
$$

in which $I$ is a measure of institutional quality. We use two types of institutional quality measures: an index of institutional quality (a continuous variable) and the existence of a fiscal rule or a resource fund in place (a dummy variable). Coefficient $g$ measures the extent to which institutions and rules/funds can affect procyclicality (a negative coefficient would imply a reduction in procyclicality in countries with better institutions and fiscal rules/resource funds). We use a fixed effects panel regression to estimate the parameters.

The results suggest that experience with resource funds and fiscal rules has been mixed (Table 6). While the interaction term is negative, consistent with the hypothesis of a reduction in procyclicality following the adoption of fiscal rules/resource funds, it is not statistically significant. These findings are in line with the experience of many countries, with possibly the exception of cases like Botswana, Chile and Norway.

Table 6.

Impact of fiscal rules on fiscal procyclicality

\begin{tabular}{|c|c|c|c|c|c|}
\hline & I & II & III & IV & $\mathrm{V}$ \\
\hline D 1 comm. prices $(P)$ & $\begin{array}{l}0.119^{* *} \\
{[0.052]}\end{array}$ & $\begin{array}{l}0.143^{* *} \\
{[0.066]}\end{array}$ & $\begin{array}{l}0.164^{* *} \\
{[0.069]}\end{array}$ & $\begin{array}{l}0.151^{* *} \\
{[0.063]}\end{array}$ & $\begin{array}{l}0.176^{* *} \\
{[0.070]}\end{array}$ \\
\hline D 1 comm. prices $(P)^{*}$ Savings fund dummy & & $\begin{array}{l}-0.022 \\
{[0.071]}\end{array}$ & & & \\
\hline D 1 comm. prices $(P)^{*}$ Stabilization fund dummy & & & $\begin{array}{c}-0.058 \\
{[0.064]}\end{array}$ & & \\
\hline D 1 comm. $\operatorname{prices}(P)^{*}$ Fiscal rule dummy & & & & $\begin{array}{l}-0.078 \\
{[0.088]}\end{array}$ & \\
\hline D 1 comm. prices $(P)^{*}$ Fiscal rule or savings/stabili & ation fun & mmy $(I)$ & & & $\begin{array}{c}-0.075 \\
{[0.063]}\end{array}$ \\
\hline Constant & $\begin{array}{l}0.124^{* *} \\
{[0.058]}\end{array}$ & $\begin{array}{c}0.123^{*} \\
{[0.073]}\end{array}$ & $\begin{array}{c}0.125^{*} \\
{[0.073]}\end{array}$ & $\begin{array}{c}0.125^{*} \\
{[0.073]}\end{array}$ & $\begin{array}{c}0.128^{*} \\
{[0.073]}\end{array}$ \\
\hline Observations & 902 & 718 & 718 & 718 & 718 \\
\hline Number of countries & 41 & 34 & 34 & 34 & 34 \\
\hline $\mathrm{R}^{\wedge} 2$ & 0.079 & 0.083 & 0.084 & 0.084 & 0.085 \\
\hline
\end{tabular}

Note: Dependent variable is real expenditure growth rate. Estimations are performed using the fixed effects estimator with AR(1) residuals and time effects. Robust standard errors are in brackets. ${ }^{*},{ }^{* *}$, and ${ }^{* * *}$ denote significance at 10, 5, and 1 percent levels, respectively.

Source: IMF World Economic Outlook and authors' calculations. 
The reasons for this lack of success are varied. The existence of a fiscal rule or fiscal fund does not necessarily indicate $a$ de facto compliance with the rule. Many rules tend to be breached especially in bad times. Lack of compliance could be due to several factors, such as lack of political will, poor design of the rule and absence of monitoring and enforcement bodies. In Nigeria, for example, the rule was repeatedly undermined by weak enforcement. In other countries, like Chad, Ecuador, and Timor Leste, rules were breached as they became incompatible with budget and developmental priorities. In some other cases, due to the rule design, governments embarked in extra-budgetary operations which made the rules ineffective and weakened budgetary control. In other cases, lack of coordination between the activities related to a resource fund and ordinary budgetary operations resulted in accumulation of financial assets in funds at times when governments had to borrow expensively to finance deficits (Ghana and Trinidad and Tobago). ${ }^{9}$

There is empirical support, however, that the quality of political institutions helps limit the procyclical bias in spending. ${ }^{10}$ In some cases the impact can be highly significant as shown in Table 7. For example, procyclicality would be eliminated in countries with the degree of bureaucratic quality or quality of institutional and legal setting around two standard deviations above the mean. In part, this reflects the fact that the average quality of institutions tends to be weaker in resource-rich countries than in other countries (Figure 4). This evidence also suggests that the lack of success of rules and funds in some countries may owe more to the underlying weaknesses of their institutional frameworks than to the rules themselves.

Table 7.

Impact of institutions on fiscal procyclicality

\begin{tabular}{|c|c|c|c|c|c|c|}
\hline & I & II & III & IV & $\mathrm{V}$ & VI \\
\hline D 1 comm. prices $(P)$ & $\begin{array}{l}0.119^{* *} \\
{[0.052]}\end{array}$ & $\begin{array}{c}0.142^{*} \\
{[0.076]}\end{array}$ & $\begin{array}{l}0.341^{* * *} \\
{[0.090]}\end{array}$ & $\begin{array}{l}0.214^{* *} \\
{[0.095]}\end{array}$ & $\begin{array}{l}0.609^{* * *} \\
{[0.178]}\end{array}$ & $\begin{array}{l}0.266^{* *} \\
{[0.115]}\end{array}$ \\
\hline D 1 comm. prices $(P) *$ Polity & & $\begin{array}{l}-0.008 \\
{[0.006]}\end{array}$ & & & & \\
\hline \multicolumn{3}{|c|}{ D 1 comm. prices $(P) *$ Bureaucratic quality } & $\begin{array}{c}-0.087^{* * *} \\
{[0.029]}\end{array}$ & & & \\
\hline \multicolumn{3}{|c|}{ D 1 comm. prices $(P) *$ Corruption } & & $\begin{array}{c}-0.027 \\
{[0.024]}\end{array}$ & & \\
\hline \multicolumn{3}{|c|}{ D 1 comm. prices $(P) *$ Political risk } & & & $\begin{array}{c}-0.007^{* * *} \\
{[0.002]}\end{array}$ & \\
\hline \multicolumn{4}{|c|}{ D 1 comm. prices $(P)^{*}$ Institutional and legal setting } & & & $\begin{array}{l}-0.003^{*} \\
{[0.001]}\end{array}$ \\
\hline Constant & $\begin{array}{l}0.124^{* *} \\
{[0.058]}\end{array}$ & $\begin{array}{c}0.155^{*} \\
{[0.086]}\end{array}$ & $\begin{array}{c}0.05 \\
{[0.055]}\end{array}$ & $\begin{array}{c}0.039 \\
{[0.056]}\end{array}$ & $\begin{array}{c}0.034 \\
{[0.028]}\end{array}$ & $\begin{array}{l}0.127^{* *} \\
{[0.060]}\end{array}$ \\
\hline Observations & 902 & 464 & 805 & 805 & 804 & 716 \\
\hline Number of countries & 41 & 22 & 41 & 41 & 41 & 33 \\
\hline $\mathrm{R}^{\wedge} 2$ & 0.079 & 0.101 & 0.089 & 0.079 & 0.088 & 0.092 \\
\hline
\end{tabular}

Note: Dependent variable is real expenditure growth rate. Estimations are performed using the fixed effects estimator with AR(1) residuals and time effects. Robust standard errors are in brackets. ${ }^{* * *}$, and ${ }^{* * *}$ denote significance at 10,5 , and 1 percent levels, respectively.

Source: IMF World Economic Outlook and authors' calculations.

\footnotetext{
9 See Ossowski et al. (2008) and Sugawara (2014) for a review.

10 These results are similar to those found in earlier studies (Ossowski et al., 2008). Frankel et al. (2013) also stress the importance of quality of institutions, while Akitoby et al. (2004) argue strengthening checks and balances can also help reduce the cyclicality of government expenditures.
} 
Some countries have been successful in limiting the negative impact of the commodity prices volatility and promote sustainable economic growth. Namely, the quality of institutions in Norway, Chile, and Botswana is higher than among their peers, which helped support fiscal policy and achieve stronger higher long-term growth (see Figure 2). They also show that fiscal rules or resource funds can help achieve policy objectives if they are supported by strong institutions and political commitment, are well-designed, and are closely linked to broader policy objectives. The examples of Chile and Norway show that the rules can both help discipline policies and allow for flexibility to respond to economic conditions - thanks to large financial buffers built during resource booms and strong market credibility. ${ }^{11,12}$

\section{Figure 4.}

Institutional quality in resource-rich countries is weaker than in other countries

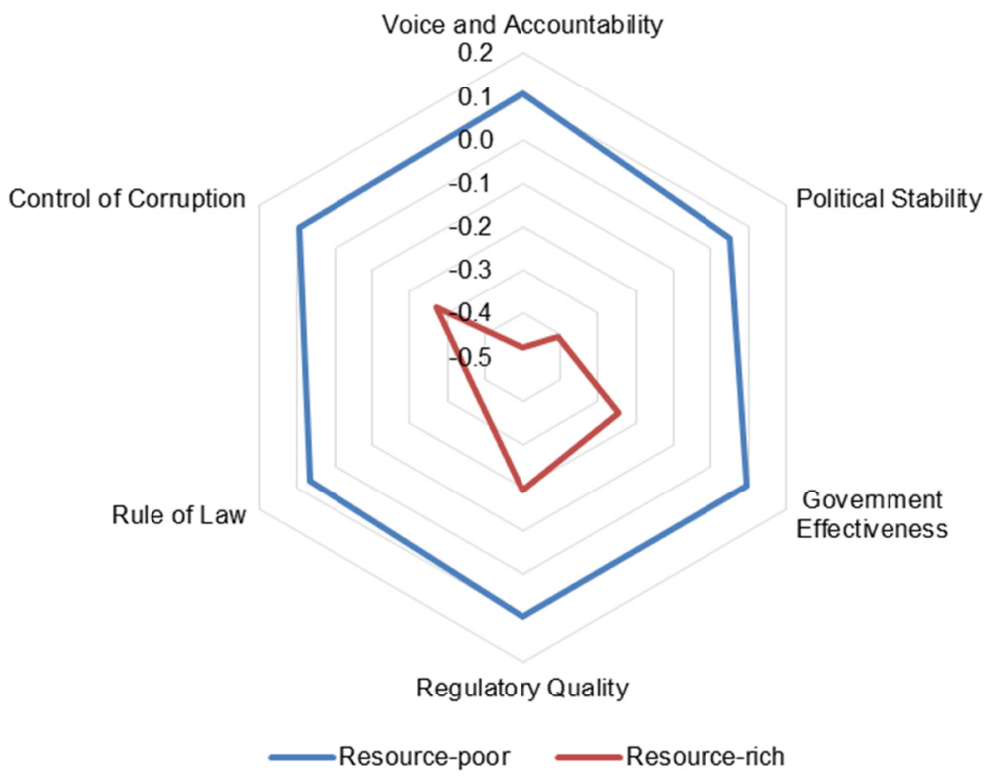

Note: The chart shows average levels of institutional quality for resource-rich and resource-poor countries with the same level of GDP per capita (sample average for resource-rich countries). Larger numbers indicate higher institutional quality. Sample period: $1996-2014$.

Source: Worldwide Governance Indicators (World Bank) and authors' estimates.

\section{HOW DO NON-RESOURCE REVENUES RESPOND TO COMMODITY REVENUE SHOCKS?}

In this section we analyze how non-resource revenues react to fluctuations in commodity revenues (heavily influenced by commodity prices). Most of previous studies on how resourcerich countries react to commodity price shocks have focused on expenditure - as, indeed, it tends to be the main channel. However, countries can also respond to shocks by changing their tax effort.

\footnotetext{
11 The strong institutional framework allowed Chile to react in a countercyclical fashion to the sudden and large $2008-09$ commodity price fall. During the commodity boom, Chile increase their net financial assets significantly. This allowed a large easing of fiscal policy in $2008-09$ in response to the global financial crisis (went from a 8 percent overall surplus in 2007 to a 4 percent fiscal deficit in 2009). See also Frankel (2011) for further discussion on Chile.

12 The Norwegian fiscal framework is anchored on a strong political commitment to a non-oil balance target. Oil/gas revenue is saved in an oil fund and only the returns from financial investments are used to fund the budget. Under the framework, the non-oil deficit should average 4 percent of the assets in the oil fund over the economic cycle. The rule allows to insulate the budget from yearly movements in the oil and gas prices. Norway's framework has not only resulted in the buildup of large financial savings, but also helped sustain GDP per capita growth above most other resource-rich countries over the last 4 decades.
} 
The existing studies assess the reaction of non-resource revenues to persistent changes in commodity revenues in oil/gas exporters (see Bornhorst et al., 2009; Thomas and Trevino, 2013; Crivelli and Gupta, 2014). They find that countries tend to offset rising commodity revenue by a reduction in non-resource tax effort. ${ }^{13}$

We expand the analysis in two main directions: (i) we use a broader set of commodity exporters and scale the commodity and non-commodity revenues by the non-commodity GDP to alleviate the endogenous impact of commodity price changes on the denominator, and (ii) we analyze both long-run and short-run reaction to changes in commodity revenues using the Pooled Mean Group (PMG) estimator of Pesaran et al. (1999). The empirical specification is:

$$
\Delta\left(\frac{R_{i t}^{N C}}{Y_{i t}}\right)=\phi_{i}\left[\frac{R_{i t}^{N C}}{Y_{i t}}-\alpha-\beta \frac{R_{i t}^{C}}{Y_{i t}}\right]+\delta_{i} \Delta\left(\frac{R_{i t}^{C}}{Y_{i t}}\right)+\mu_{i}+\varepsilon_{i t}
$$

in which $i$ and $t$ indexes denote country and time, $Y$ is the nominal GDP (non-commodity), $R$ is government non-commodity $(N C)$ and commodity $(C)$ revenues, $\mu$ is the country-specific fixed effect, and $\varepsilon$ is an i.i.d. error term. The term in the squared bracket is the error-correction term measuring the extent of the deviation of the non-commodity revenue from its long-run equilibrium value. $\beta$ measures the long-run reaction of non-commodity revenues to a permanent change in commodity revenues and corresponds to the coefficient estimates in Bornhorst et al. (2009) and Crivelli and Gupta (2014). Similarly, $\delta$ measures the short-term effect of non-commodity revenue to a temporary change in non-commodity revenue. $\phi$ is the speed of adjustment of noncommodity revenue to its long-run equilibrium: the larger is the coefficient (in absolute terms), the faster is the adjustment. Finally, the country-specific fixed effects included in the specification capture unobserved heterogeneity of non-commodity revenue across different countries.

Our results suggest that resource-rich countries adjust tax effort in response to persistent changes in commodity revenues, but there is limited reaction to temporary changes. Table 8 shows that a permanent increase in commodity revenues by 1 percent of non-commodity GDP tends to reduce non-commodity revenues by $0.03-0.04$ percent of non-commodity GDP. Temporary changes in commodity revenues (up to 3 years lag) do not have a significant impact on non-commodity revenues. Countries do not seem to change non-commodity revenue effort in response to temporary commodity revenue shocks, letting the automatic stabilizers work. In addition, half of the deviation from the long run association between commodity and noncommodity revenues is corrected in 4 years, providing further evidence on the sluggish adjustment of non-commodity revenues.

Table 8.

Impact of commodity revenue shocks on non-commodity revenues

\begin{tabular}{lccc}
\hline \hline & I & II & III \\
\hline Long-run coefficients & & & \\
& & & \\
Comm. revenue/non-comm. GDP $\left(\frac{\boldsymbol{R}_{i t}^{C}}{\boldsymbol{Y}_{\text {it }}}\right)(1 \mathrm{lag})$ & $-0.033^{* * *}$ & $-0.035^{* * *}$ & $-0.040^{* * *}$ \\
& {$[0.007]$} & {$[0.008]$} & {$[0.007]$} \\
Constant & $19.576^{* * *}$ & $19.829^{* * *}$ & $20.006^{* * *}$ \\
& {$[0.412]$} & {$[0.463]$} & {$[0.380]$} \\
\hline
\end{tabular}

A 1 percent of GDP increase in hydrocarbon revenues leads to about 0.2 percent reduction of non-hydrocarbon revenues over the long-run (Bornhorst et al., 2009). 
I

Short-run coefficients

D Comm. revenue/non-comm. GDP $\left(\frac{R_{i t}^{C}}{Y_{i t}}\right)$

D Comm. revenue/non-comm. GDP $\left(\frac{R_{i t}^{C}}{Y_{i t}}\right)(1 \mathrm{lag})$

D Comm. revenue/non-comm. GDP $\left(\frac{R_{i t}^{C}}{Y_{i t}}\right)$ (2 lags)

Observations

Log likelihood

Half life (years)
Speed of adjustment

$-0.156^{* * *}$

[0.042]

$-0.072$

[0.075]

(0.075)

Note: Dependent variable is the change in non-commodity revenue ratio. Estimations are performed using the Pooled Mean Group (PMG) estimator. ${ }^{* * *}$, and ${ }^{* * *}$ denote significance at 10,5 , and 1 percent levels, respectively.

Source: authors' calculations.

\section{CONCLUSIONS}

Using a novel dataset for resource-rich economies, this study aims at providing a comprehensive analysis on fiscal policy responses to the commodity price fluctuations. It does so by examining several channels through which fiscal policy can react to commodity price shocks. First, it provides evidence of the impact that commodity price shocks (both upswings and downswings) have on exports and fiscal revenue of a resource-rich country. Second, it examines three sets of policy responses. First, it focuses on the way total and capital expenditures react to commodity prices. Second, it assesses the implication of price changes on the non-resource fiscal balances; and third, it looks at the response to price shocks of non-resource revenues, as an additional countercyclical measure that can be adopted by the government.

We find that fiscal policy in resource-rich countries tends to be procyclical and more so than for other economies. Contrary to other studies, we do not find evidence that procyclicality has declined over time. Such procyclicality is found when looking at the reaction of expenditure and of the non-resource balance to commodity prices. We also find some tax effort in response to changes in commodity revenues, but only when these changes are persistent. Finally, we find that adoption of fiscal rules or resource funds do not have a significant impact on fiscal cyclicality, but general political institutions do help. The lack of progress on these likely partly explains why fiscal procyclicality, on average, has not declined in recent years.

Our results have important policy implications. First, more efforts are needed to establish a comprehensive fiscal policy framework in resource-rich countries that can help cope with heightened uncertainty and volatility. These frameworks should be based on a solid long-term anchor to guide fiscal policy and should explicitly incorporate commodity price uncertainty. This means putting more emphasis on building precautionary savings during good times to help weather shocks in a countercyclical fashion. Next, further efforts to improve the institutional framework are needed, including enhancing transparency and accountability. Tax policies aimed at diversifying the revenue base would reduce government's overdependence on commodity revenues and improve its ability to run countercyclical policies. Finally, efforts to diversify the economy beyond the commodity sector are also critical. 


\section{APPENDIX}

Table A1.

Resource Funds and Rules

\begin{tabular}{|c|c|c|c|c|c|c|c|}
\hline & \multirow{2}{*}{$\begin{array}{l}\mathrm{SWF}^{*} \\
\mathrm{Yes}=1 \\
\mathrm{No}=0\end{array}$} & \multicolumn{2}{|c|}{ Saving Fund } & \multicolumn{2}{|c|}{ Stabilization Fund } & \multicolumn{2}{|c|}{ Fiscal Rule } \\
\hline & & $\begin{aligned} \text { Yes } & =1 \\
\text { No } & =0\end{aligned}$ & Dates & $\begin{aligned} \mathrm{Yes} & =1 \\
\mathrm{No} & =0\end{aligned}$ & Dates & $\begin{aligned} \text { Yes } & =1 \\
\text { No } & =0\end{aligned}$ & Dates \\
\hline Algeria & 1 & 0 & & 1 & 2000 & 0 & \\
\hline Angola & 1 & 1 & 2012 & 1 & 2012 & 0 & \\
\hline Azerbaijan & 1 & 1 & 1999 & 1 & 1999 & 1 & 1999 \\
\hline Bahrain & 1 & 0 & & 1 & 2000 & 0 & \\
\hline Bolivia & 0 & 0 & & 0 & & 0 & \\
\hline Botswana & 1 & 1 & 1993 & 1 & 1972 & 1 & 1994 \\
\hline Brunei Darussalam & 0 & 0 & & 0 & & 0 & \\
\hline Cameroon & 0 & 0 & & 0 & & 0 & \\
\hline Chad & 1 & 1 & 2008 & 1 & 2008 & 0 & \\
\hline Chile & 1 & 1 & 1985 & 1 & 1985 & 1 & 2006 \\
\hline Colombia & 1 & 0 & & 1 & 1995 & 0 & \\
\hline Congo & 0 & 0 & & 0 & & 0 & \\
\hline Congo DRC & 0 & 0 & & 0 & & 0 & \\
\hline Cote D'Ivoire & 0 & 0 & & 0 & & 0 & \\
\hline Equatorial Guinea & 1 & 1 & 2002 & 0 & & 1 & 2002 \\
\hline Ecuador & 1 & 1 & 2005 & 1 & 1999-2007 & 1 & 2002 \\
\hline Gabon & 1 & 1 & 1998 & 0 & & 1 & 1998 \\
\hline Ghana & 1 & 1 & 2011 & 1 & 2011 & 1 & 2011 \\
\hline Guinea & 0 & 0 & & 0 & & 0 & \\
\hline Guyana & 0 & 0 & & 0 & & 0 & \\
\hline Indonesia & 0 & 0 & & 0 & & 0 & \\
\hline Iran & 1 & 0 & & 1 & 2000 & 0 & \\
\hline Iraq & 0 & 0 & & 0 & & 0 & \\
\hline Kazakhstan & 1 & 1 & 2000 & 1 & 2000 & 1 & 2000 \\
\hline Kuwait & 1 & 1 & 1960 & 1 & 1960 & 0 & \\
\hline Libya & 1 & 1 & 1995 & 0 & & 0 & \\
\hline Mali & 0 & 0 & & 0 & & 0 & \\
\hline Mauritania & 1 & 0 & & 1 & 2000 & 0 & \\
\hline Mexico & 1 & 0 & & 1 & 2000 & 0 & \\
\hline Mongolia & 1 & 0 & & 1 & 2011 & 0 & \\
\hline Mozambique & 0 & 0 & & 0 & & 0 & \\
\hline Niger & 0 & 0 & & 0 & & 0 & \\
\hline
\end{tabular}




\begin{tabular}{|c|c|c|c|c|c|c|c|}
\hline & \multirow{2}{*}{$\begin{array}{l}\text { SWF }^{*} \\
\text { Yes }=1 ; \\
\text { No }=0\end{array}$} & \multicolumn{2}{|c|}{ Saving Fund } & \multicolumn{2}{|c|}{ Stabilization Fund } & \multicolumn{2}{|c|}{ Fiscal Rule } \\
\hline & & $\begin{array}{l}\text { Yes }=1 \\
\text { No }=0\end{array}$ & Dates & $\begin{aligned} \text { Yes } & =1 \\
\text { No } & =0\end{aligned}$ & Dates & $\begin{array}{l}\text { Yes }=1 \\
\text { No }=0\end{array}$ & Dates \\
\hline Nigeria & 1 & 1 & 2011 & 1 & 2004 & 0 & \\
\hline Norway & 1 & 1 & 1985 & 1 & 1985 & 1 & 2002 \\
\hline Oman & 1 & 1 & 1980 & 0 & & 0 & \\
\hline Papua New Guinea & 1 & 0 & & 1 & 1974-2001 & 0 & \\
\hline Peru & 1 & 0 & & 1 & 1999 & 0 & \\
\hline Qatar & 1 & 0 & & 1 & 2000 & 0 & \\
\hline Russia & 1 & 0 & & 1 & 2004 & 1 & 2008 \\
\hline Saudi Arabia & 0 & 0 & & 0 & & 0 & \\
\hline Sudan & 1 & 0 & & 1 & 2002 & 0 & \\
\hline Suriname & 0 & 0 & & 0 & & 0 & \\
\hline Syria & 0 & 0 & & 0 & & 0 & \\
\hline Timor Leste & 1 & 1 & 2005 & 1 & 2005 & 1 & 2005 \\
\hline $\begin{array}{l}\text { Trinidad and } \\
\text { Tobago }\end{array}$ & 1 & 1 & 1999 & 1 & 2005 & 1 & 2007 \\
\hline UAE & 0 & 0 & & 0 & & 0 & \\
\hline Venezuela & 1 & 1 & 1999 & 0 & & 1 & 2000 \\
\hline Yemen & 0 & 0 & & 0 & & 0 & \\
\hline Zambia & 0 & 0 & & 0 & & 0 & \\
\hline
\end{tabular}

Sovereign Wealth Funds (SWF) here capture only saving and stabilization funds.

Source: IMF internal dataset.

\section{References}

Abdih Y., Lopez-Murphy P., Roitman A., Sahay R. (2010) The Cyclicality of Fiscal Policy in the Middle East and Central Asia: Is the Current Crisis Different?. IMF Working Paper 10/68. Washington: International Monetary Fund.

Akitoby B., Clements B., Gupta S., Inchauste, G. (2004) The Cyclical and Long-Term Behavior of Government Expenditures in Developing Countries. IMF Working Paper 04/202.

Akitoby B., Clements, B., Gupta S., Inchauste, G. (2006) Public Spending, Voracity, and Wagner's Law in Developing Countries. European Journal of Political Economy No 22, pp. 908-924.

Alesina A., Campante F., Tabellini G. (2008) Why is Fiscal Policy Often Procyclical? Journal of the European Economic Association No 5, pp. 1006-1036.

Arezki R., Hamilton K., Kazimov K. (2011) Resource Windfalls, Macroeconomic Stability and Growth: The Role of Political Institutions, IMF Working Paper 11/142, Washington: International Monetary Fund.

Bornhorst F., Gupta S., Thornton J. (2009) Natural Resource Endowments and the Domestic Revenue Effort. European Journal of Political Economy No 25, pp. 439-446.

Cashin P., McDermott J., Scott A. (2002) Booms and Slumps in World Commodity Prices. Journal of Development Economics No 69, pp. 277-296.

Cespedes L., Velasco A. (2014) Was This Time Different?: Fiscal Policy in Commodity Republics. Journal of Development Economics No 106, pp. 92-106.

Crivelli E., Gupta S. (2014) Resource Blessing, Revenue Curse? Domestic Revenue Effort in Resource-Rich Countries. European Journal of Political Economy No 35, pp. 88-101. 
Erbil N., (2011) Is fiscal policy procyclical in developing oil-producing countries? IMF Working Paper WP/11/171, Washington: International Monetary Fund.

International Monetary Fund (2015a) October Fiscal Monitor The Commodities Rollercoaster: A Fiscal Framework for Uncertain Times, Washington: International Monetary Fund.

-. (2015b) April Fiscal Monitor Now is the Time: Fiscal Policies for Sustainable Growth Washington: International Monetary Fund.

Fatas A., Mihov I. (2003) The Case for Restricting Fiscal Policy Discretion. Quarterly Journal of Economics No 118, pp. 1419-1447.

Frankel J., Vegh C., Vulletin G. (2013) On Graduation from Fiscal Procyclicality. Journal of Development Economics No 100, pp. 32-47.

Frankel J. (2011) A Solution to Fiscal Procyclicality: The Structural Budget Institutions Pioneered by Chile. NBER Working Paper No 16945, Cambridge, MA.

Gali J., Perotti R. (2003) Fiscal Policy and Monetary Integration in Europe. Economic Policy No 18, pp. 533-572.

Gavin M., Perotti R. (1997) Fiscal Policy in Latin America. In NBER Macroeconomics Annual, edited by Ben S. Bernanke and Julio J. Rotemberg. Cambridge, Massachusetts: MIT Press.

Gelb A. and associates. (1998) Oil windfalls: Blessing or curse? Oxford University Press.

Ghosh, A.R., Kim J.I., Qureshi M.S. (2010) Fiscal space. Washington: International Monetary Fund, Research Department.

Gourinchas P., Obstfeld M. (2011). Stories of the twentieth century for the twenty-first. National Bureau of Economic Research No. w17252.

Harding D., Pagan A. (2002) Dissecting the cycle: A methodological investigation. Journal of Monetary Economics No 49, pp. 365-381.

Husain A., Tazhibayeva K., Ter-Martirosyan A. (2008) Fiscal Policy and Economic Cycles in Oil-Exporting Economies. IMF Working Paper 08/253, Washington: International Monetary Fund.

Kaminsky G., Reinhart C., Vegh. C. (2004) When It Rains, It Pours: Procyclical Capital Flows and Macroeconomic Policies. NBER Macroeconomics Annual No 19, pp. 11-82.

Manzano O., Rigobon R. (2001) Resource Curse or Debt Overhang. NBER Working Paper 8390, Cambridge MA.

Ossowski R., Villafuerte M., Medas P., Thomas T. (2008) The Role of Fiscal Institutions in Managing the Oil Revenue Boom. IMF Occasional Paper 260, Washington: International Monetary Fund.

Pesaran H., Shin Y., Smith R. (1999) Pooled Mean Group Estimation of Dynamic Heterogeneous Panels. Journal of the American Statistical Association No 94, pp. 621-34.

Schaechter A., Kinda T., Budina N., Weber A (2012) Fiscal Rules in Response to the Crisis - Toward the "NextGeneration" Rules. A New Dataset. IMF Working Paper 12/187, Washington: International Monetary Fund.

Sugawara N. (2014) From Volatility to Stability in Expenditure: Stabilization Funds in Resource Rich Countries. IMF Working Paper 14/43, Washington: International Monetary Fund

Thomas A., Treviño J. (2013) Resource Dependence and Fiscal Effort in Sub-Saharan Africa. IMF Working Paper 13/188, Washington: International Monetary Fund.

Van Der Ploeg F., Poelhekke S. (2008) Volatility and the Natural Resource Curse. OxCarre Research Paper 3, Oxford University: Centre for the Analysis of Resource-Rich Economies.

Villafuerte M., Lopez-Murphy P., Ossowski R. (2010) Riding the Roller Coaster: Fiscal Policies of Nonrenewable Resource Exporters in Latin America and the Caribbean. IMF Working Paper 10/251, Washington: International Monetary Fund.

Westerlund J. (2007) Testing for Error Correction in Panel Data. Oxford Bulletin of Economics and Statistics No 69, pp. 709-748.

World Bank (2009) Global Economic Prospects. Washington: World Bank. 